УДК 330.322

\title{
СОЦІАЛЬНІ ІНВЕСТИЦЇ̈ ЯК ПРОВІДНИЙ ІНСТРУМЕНТ КОРПОРАТИВНОЇ СОЦІАЛЬНОЇ ВІДПОВІДАЛЬНОСТІ
}

\author{
Панченко Н.Г., к.е.н., доцент (УкрДУЗТ)
}

Загострення сочіальних проблем в Україні пов'язано не тільки з глобальною кризою, а й з надмірно тривалими реформа. Непослідовність прийнятих управлінських рішень, крім усього іншого, перешкоджає відродженню в суспільстві довіри до владних структур, щуо стримує розвиток сочіальної сфери. Така ситуачія природно обумовлює пошук нових шляхів і організаційно-економічних інструментів досягнення соціального благополуччя в суспільстві. Одним з таких способів має стати активний розвиток бізнесу, так як організації, що займаються підприємницькою діяльністю, зобов'язані нести певну відповідальність перед суспільством (соціумом) в процесі розвитку якого вони $i$ з'явилися. Автором запропоновано під сочіальними інвестиціями розуміти матеріальні, технологічні, управлінські, добровольчі чи інші ресурси, а також фінансові кошти, щчо використовуються, як правило, з частини прибутку підприємства та спрямовуються за рішенням керівництва на реалізацію соціальних програм, розроблених з урахуванням інтересів основних внутрішніх $i$ зовнішніх зацікавлених сторін (стейкхолдерів) у припущенні, щзо у стратегічному (рідше тактичному) щодо компанією буде отриманий соиіальний або економічний ефект.

Ключові слова: корпоративна соціальні відповідальність, підприємство, соціальні інвестицї, об'єкти соціального інвестування, бізнес-альтруїзм

\section{СОЦИАЛЬНЫЕ ИНВЕСТИЦИИ КАК ВЕДУЩИЙ ИНСТРУМЕНТ КОРПОРАТИВНОЙ СОЦИАЛЬНОЙ ОТВЕТСТВЕННОСТИ}

\author{
Панченко Н.Г., к.э.н., доцент (УкрГУЖТ)
}

Обострение социальных проблем в Украине связано не только с глобальным кризисом, но и с чрезмерно длительными реформами. Непоследовательность принимаемых управленческих решений, кроме всего прочего, препятствует возрождению в обществе доверия к властным структурам, что сдерживает развитие соииильной сферы. Такая ситуация естественно обуславливает поиск новых путей и организационно-экономических инструментов достижения сочиального благополучия в обществе. Одним из таких способов должно стать активное развитие бизнеса, так как организации, занимающиеся предпринимательской деятельностью, обязаны нести определенную ответственность перед обществом (сочиумом), в проиессе развития которого они и появились. Автором предложено под социальными инвестициями понимать материальные, технологические, управленческие, добровольческие или иные ресурсы, а также финансовые средства, используемые, как правило, из части прибыли предприятия и направляемые по решению руководства на реализацию социальных программ, разработанных с учетом интересов основных внутренних и внешних заинтересованных сторон (стейкхолдеров) в предположении, что в стратегическом (реже тактическом) отношении компанией будет получен сочиальный или экономический эффект.

Ключевье слова: корпоративная социальная ответственность,

(C) Панченко Н.Г.

Вісник економіки транспорту і промисловості № 63, 2018 
предприятие, социальные инвестиции, объекты социального инвестирования, бизнес-альтруизм

\title{
SOCIAL INVESTMENT AS A LEADING TOOL OF CORPORATE SOCIAL RESPONSIBILITY
}

\author{
Panchenko N.G., Ph.D. in Economics, associate Professor (USURT)
}

The aggravation of social problems in Ukraine is connected not only with the global crisis, but also with the excessively long reform. The inconsistency of management decisions, among other things, prevents the revival of public confidence in the power structures, which hinders the development of the social sphere. This situation naturally leads to the search for new ways and organizational and economic tools to achieve social well-being in society. One of these ways should be the active development of business, as organizations engaged in entrepreneurial activity, are obliged to bear some responsibility to society (society) in the development of which they appeared. The author proposes to understand social investments as material, technological, managerial, voluntary or other resources, as well as financial means used, as a rule, from the part of the company's profit and directed by the decision of the management to the implementation of social programs developed taking into account the interests of the main internal and external stakeholders (stakeholders) in the assumption that in the strategic (less tactical) respect the company will get a social or economic effect. According to this definition, it can be noted that the effect of the implementation of social investment is achieved primarily non - financial-social, marketing, organizational, environmental, etc. Achieving financial goals in its implementation is also possible, but it is not its main task. In the expanded interpretation, social investments are identified with investments that are aimed at strengthening the social orientation of the economic system: achieving environmental safety, stimulating economic growth, ensuring a guaranteed level of nutrition, education, in other words, the key is the characteristic of social investment as the activity of the subjects of investment relations aimed at obtaining a certain beneficial effect for society.

Key words: corporate social responsibility, enterprise, social investments, social investment objects, business altruism

Постановка проблеми та іï зв'язки 3 науковими чи практичними завданнями. Загострення соціальних проблем в Україні пов'язано не тільки 3 глобальною кризою, а й 3 надмірно тривалими реформа. Непослідовність прийнятих управлінських рішень, крім усього іншого, перешкоджає відродженню в суспільстві довіри до владних структур, що стримує розвиток соціальної сфери. Така ситуація природно обумовлює пошук нових шляхів і організаційно-економічних інструментів досягнення соціального благополуччя в суспільстві. Одним з таких способів має стати активний розвиток бізнесу, так як організації, що займаються підприємницькою діяльністю, зобов'язані нести певну відповідальність перед суспільством (соціумом) в процесі розвитку якого вони і з'явилися.

Актуальність вирішення питань соціального інвестування бізнесу в Україні визначається, перш за все, збільшеною роллю великих корпорацій у зростанні економіки країни; по-друге, виразною тенденцією активної включеності бізнесу у вирішення соціальних завдань розвитку суспільства; i, по-трете, практичною значимістю корпоративних соціальних програм, реалізованих на підприємствах.

Аналіз останніх досліджень i публікацій. Теоретичні підходи до визначення сутності соціального 
інвестування, механізму його реалізації та структуризації, суб'єктно-об'єктних особливостей набули достатньо широкого висвітлення в останні роки, паралельно 3 дослідженнями механізмів реалізації корпоративної соціальної відповідальності. Зокрема, на нашу думку, слід виокремити роботи С.В. Туркіна [2], А.В. Маркова [5], Н.Я. Яневич [7], Д. Шейман, К. Смирнова [8] та ін. Окремі теоретичні аспекти механізму забезпечення соціальної відповідальності бізнесу й особливостей формування системи соціальної відповідальності на підприємствах в умовах глобальної економіки розглянуто у працях С. Панченко, В. Диканя, Ю. Боровика, В. Компанієць, В. Зубенко, І. Токмакової, О. Маковоз, О. Полякової, Ю. Уткіної, О. Шраменко $[3,4,6]$.

Виділення невирішених частин загальної проблеми. Економічною наукою вивчалися форми корпоративної благодійності, структура i обсяги благодійних коштів, питання реалізації соціального партнерства, причини розбіжності інтересів бізнесу i суспільства, структура, обсяги і лідери соціальних інвестицій бізнесу. Результати цих досліджень, хоча i представляють безумовний інтерес, тим не менш, не відповідають на багато ключових питання, що виникають у процесі формування та реалізації соціальних інвестицій українських компаній $\mathrm{y}$ сучасних ринкових реаліях.

Формування цілей статті (постановка завдання). Саме тому метою статті $€$ дослідження концептуальних основ соціального інвестування як форми прояву корпоративної соціальної відповідальності бізнесу.

Виклад основного матеріалу дослідження. В кінці 60-початку 70-х років XX ст. в США, Великобританії, Японії та Німеччини стала формуватися концепція соціально відповідального бізнесу. Соціальна відповідальність в широкому розумінні виступає як певні очікування суспільства по відношенню до власників i менеджменту, виробничих структурам, з одного боку, і усвідомлення ними свого боргу перед суспільством, колективом, індивідуумом за свої дії і їхні соціальні наслідки - з іншого.

У матеріалах Європейської комісії дається таке визначення: «Корпоративна соціальна відповідальність (КСВ) за своєю суттю $€$ концепцією, яка відображає добровільне рішення компаній брати участь в поліпшенні суспільства і захисту навколишне середовище» [7].

Інструментом впливу суспільства на формування корпоративної соціальної відповідальності можуть бути соціальні інвестиції.

Соціальні інвестиції - вкладення в об'єкти соціальної сфери 3 метою отримання доходу та підвищення рівня i якості життя людей за допомогою задоволення їх матеріальних, духовних чи соціальних потреб.

Якість життя - свого роду похідна величина від рівня життя, комплексна характеристика рівня життя населення. Якість життя населення визначається низкою об'єктивних i суб'єктивних показників. Серед об'єктивних споживання матеріальних благ, продуктів харчування, якість житлових умов та зайнятості, розвиток сфери послуг, освіти, культури, соціального забезпечення. Серед суб'єктивних-задоволеність людини роботою i життевими умовами, соціальним статусом, фінансовим становищем і сімейними відносинами.

Категорія «рівень життя» в рекомендаціях ООН складається 3 таких елементів, як здоров'я, їжа, одяг, умови праці, зайнятість, освіту, житло, соціальне забезпечення. В Україні рівень життя прийнято визначати, в першу чергу, за допомогою системи споживчих бюджетів: фізіологічного, прожиткового i соціального мінімумів.

Суб'єкти соціальних інвестицій органи державної влади, державні i муніципальні підприємства, українські та іноземні приватні комерційні i некомерційні організації, фізичні особи. 
Для держави цілями соціальних інвестицій можуть бути підвищення національного доходу і рівня (якості) життя одночасно, для комерційних структур, іноземних інвесторів та фізичних осіб - прибуток, для некомерційних організацій підвищення рівня i якості життя за допомогою задоволення матеріальних, духовних i соціальних потреб. Для останніх отримання прибутку не $\epsilon$ метою соціального інвестування.

У розширеному трактуванні соціальні інвестиції ототожнюються 3 вкладеннями, що спрямовуються на посилення соціальної орієнтації економічної системи: досягнення екологічної безпеки, стимулювання економічного зростання, забезпечення гарантованого рівня харчування, освіти, інакше кажучи, ключовою $\epsilon$ характеристика соціального інвестування як діяльності суб'єктів інвестиційних відносин, спрямованої на отримання певного корисного ефекту для суспільства.

При цьому більшість дослідників зазначають, що соціальні інвестиції - одна 3 найбільш масштабних форм реалізації практик корпоративної соціальної відповідальності. Подібні інвестиції формують соціальний капітал компаній i сприяють їх сталому розвитку, підвищують інвестиційну цінність самого бізнесу. Ефективні інвестиції в соціальну сферу можливі лише при детально продуманій стратегії сталого розвитку компанії. Ці дії завжди системні, результат ж від вкладень стає очевидним після місяців або навіть років роботи. Дозволити собі таку форму корпоративної соціальної відповідальності можуть в основному компанії з високим стабільним рівнем доходу.

Також в економічній науці існує думка, що соціальні інвестиції - форма фінансової допомоги, що виділяється компанією на реалізацію довгострокових $\mathrm{i}$, як правило, спільних партнерських соціальних програм, спрямованих на зниження соціальної напруги в регіонах присутності компанії і підвищення рівня життя різних верств суспільства. Їх інтенсивність знаходиться в прямій залежності від рівня розвитку бізнесу та економіки. Бізнес-діяльність компанії та ії соціальна відповідальність тісно пов'язані. Чи не всі сфери бізнес активності більшою чи меншою мірою включають соціальнозначущі компоненти. Зокрема, наступні основних функцій бізнесу мають відношення до корпоративної соціальної відповідальності [3, 6]:

- загальна політика i стратегія: наскільки політика і стратегія компанії служать завданням сталого розвитку i приносять вигоду всім зацікавленим сторонам;

- організація праці та виробничий процес: чи дотримуються норми безпеки та екологічні норми при виробничих процесах, чи забезпечуються якість товарів та їх безпека для споживача;

$$
\text { закупівлі та управління }
$$

поставками: чи купуються товари, запчастини та послуги у місцевих постачальників, i якщо так, то чи допомагає їм компанія дотримуватися встановлених стандартів;

- збут і продаж товарів: наскільки безпечні технології збуту товарів, чи приносять відносини між підприємством і продавцем користь кінцевому споживачеві;

- продаж, маркетинг і відносини 3 клієнтами: $є$ інформація в рекламі товару $\mathrm{i}$ на його упаковці точною і правдивою, які механізми використовуються для налагодження відносин між компанією і іiі клієнтами;

- розвиток людських ресурсів i трудові відносини: умови працевлаштування працівників (у тому числі представників меншин), охорона i гігієна праці, навчання співробітників, стратегії подолання негативних наслідків реструктурування, скорочення штатів і т. д.;

- фінансове управління і відносини 3 інвесторами: ефективність фінансового контролю, відкритість документації, 
якість роботи керівництва підприємства, ставлення до хабарів і внутрішніх торгових операцій;

- проектно-конструкторські роботи: обсяг вкладень, облік соціальних чи екологічних проблем, створення проектноконструкторських бюро в місцях освоєння нових ринків; відносини 3 владою: забезпечується відкритість та прозорість у відносинах 3 владою i в лобістської діяльності; бере участь компанія у діалозі між приватним і державним секторами для покращення політики i норм, що регулюють такі сфери, як працевлаштування, природоохоронні норми і т. д.;

відносини 3 іншими зацікавленими сторонами: як будуються відносини $з$ місцевим населенням, чи бере участь компанія в суспільному житті, наскільки відкриті компанія та іiі підрозділи для місцевого населення;

- заходи з охорони навколишнього середовища: чи $\epsilon$ у компанії своя природоохоронна політика, чи проводиться екологічна експертиза нових проектів і товарів, чи звітує компанія перед громадськістю про свій вплив на навколишнє середовище.

Практика показує, що компанії ставлять різні цілі при реалізації соціальних проектів i програм. Всі проекти і програми розвитку соціальної сфери можна розділити на рентабельні $(\mathrm{NPV}>0)$ і витратні $(\mathrm{NPV} \leq 0)$. Також соціальні проекти можна класифікувати за спрямованістю: спрямовані на внутрішнє середовище компанії (співробітників) i зовнішню середу (зацікавлених осіб). Напрямків інвестування може бути значно більше, тому виділимо 8 основних блоків (див. рис. 1).

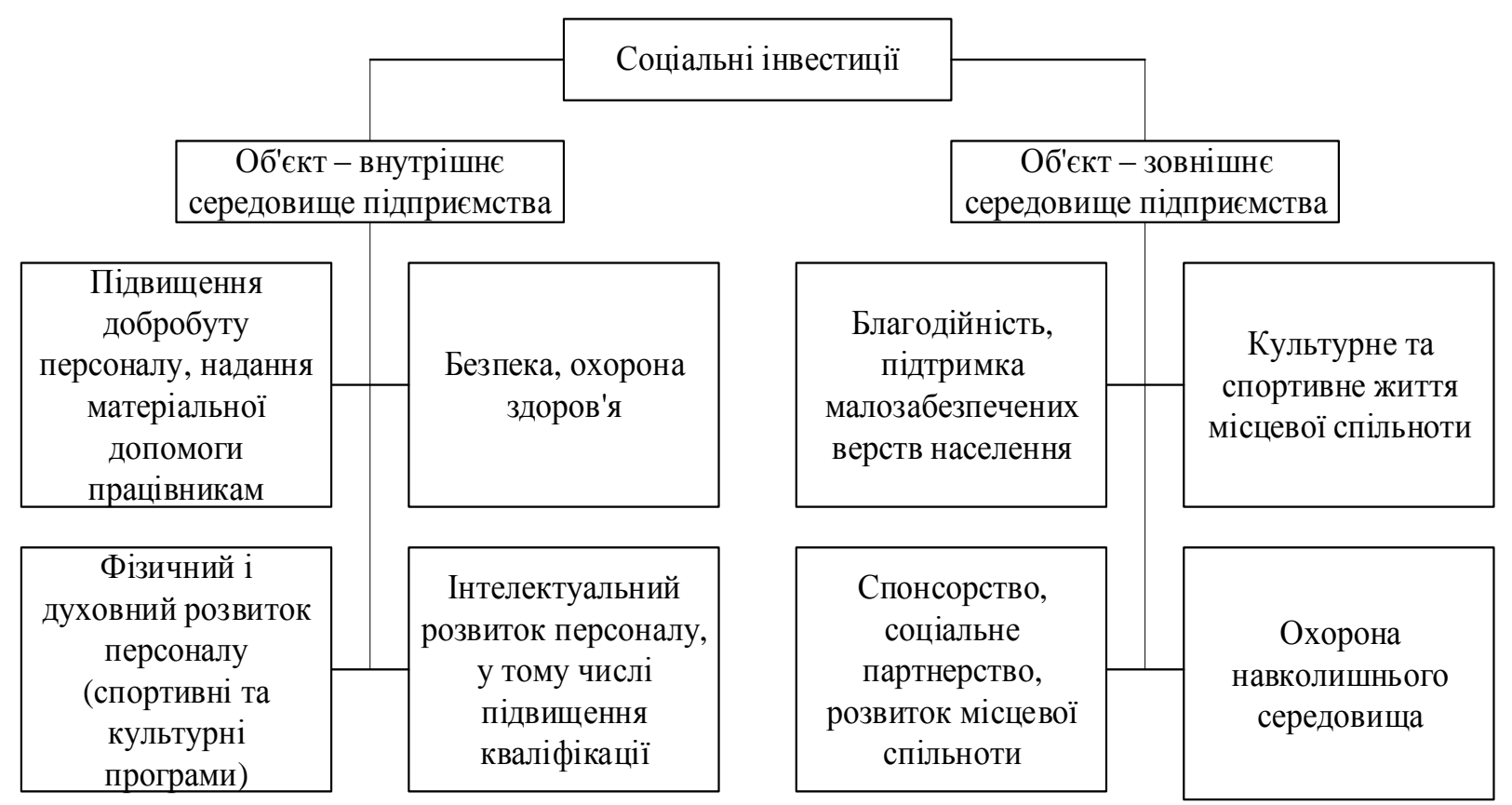

Рис. 1. Напрямки соціального інвестування у залежності від об 'єкту

Соціальне комерційних інвестування компаніях родинно альтруїзму в людському суспільстві (від альтруїзму соціальні інвестиції відділяє лише раціональність і націленість на результат). Сучасні дослідження підтверджують, що альтруїзм - це в природне прагнення людства, в тій чи іншій мірі властиве всім індивідам. Вивчаючи сучасні теорії, що моделюють розвиток соціальних систем і пояснюють поведінку людини в сучасному суспільстві (теорія спорідненого відбору Гамільтона, теорія макіавеллівського інтелекту) [5], 
можна прийти до висновку, що існує і так званий «механізм взаємного альтруїзму». Дія даного механізму можна описати фразою «відповідай добром на добро». Тобто людина або людська спільнота реагують на прояви альтруїзму іншими істотами і з більшою часткою ймовірності дадуть відповідь рівним вчинком. Так може утворитися ланцюжок соціально корисних дій, заснованих лише на одному прагненні до здійснення добрих вчинків. Однак надмірна присутність «альтруїстів» в суспільстві призводить до нераціонального витрачання ресурсів i, як наслідок, зниження ефективності в цілому. Існує і теорія, згідно з якою в суспільстві $є$ і певна частка «паразитів» (i вона дуже велика), тобто істот, які користуються благими намірами альтруїстів i «маскують» свою діяльність під доброту [2].

\begin{tabular}{lcr}
\multicolumn{1}{c}{ Однак, на основі } & проведеного \\
дослідження, & a також & аналізуючи \\
конкретні & приклади & соціального \\
інвестування в Україні і & за кордоном, \\
нами зроблено висновок & про те, що \\
переважна & більшість & соціальних
\end{tabular} інвестицій далекі від альтруїзму в його загальноприйнятому значенні. Соціальне інвестування - це, перш за все, цілеспрямований процес, який в тій чи іншій мірі сприяє досягненню позитивного результату для підприємства. При цьому, якщо розглядати цілі підприємства в рамках стратегічного планування (відповідно до ієрархії цілей, де головна - виживання у зовнішньому та внутрішньому середовищі), можна дійти висновку, що соціальні інвестиції є однією з форм прояву бізнес-альтруїзму. Тобто в рамках соціального інвестування, насамперед, реалізується завдання 3 досягнення певного ефекту для групи зацікавлених осіб. Воно може також сприяти досягненню однієї або декількох стратегічних цілей організації (в тому числі за рахунок прояву «механізму взаємного альтруїзму»). Ступінь прояву бізнес-альтруїзму в рамках соціального інвестування може залежати від цілей проекту, його напрямів та залучення зацікавлених осіб.

Висновки даного дослідження i перспективи подальших робіт у цьому напрямку. Таким чином, на нашу думку, під соціальними інвестиціями доцільно розуміти матеріальні, технологічні, управлінські, добровольчі чи інші ресурси, a також фінансові кошти, що використовуються, як правило, з частини прибутку підприємства та спрямовуються за рішенням керівництва на реалізацію соціальних програм, розроблених 3 урахуванням інтересів основних внутрішніх i зовнішніх зацікавлених сторін (стейкхолдерів) у припущенні, що у стратегічному (рідше тактичному) щодо компанією буде отриманий соціальний або економічний ефект. За даним визначенням, можна зазначити, що ефект від реалізації соціального інвестування досягається, насамперед, нефінансовий соціальний, маркетинговий, організаційний, екологічний i т.д. Досягнення фінансових цілей при його реалізації також можливе, але воно не $є$ основним його завданням.

\section{ПЕРЕЛІЕ ВИКОРИСТАНИХ ДЖЕРЕЛ}

1. Охріменко, О.О. Соціальна відповідальність [Текст]: навч. посіб. // О.О. Охріменко, Т.В. Іванова. - К.: НТУУ «КПІ», 2015. - $180 \mathrm{c}$.

2. Туркин С.В. Зачем бизнесу социальная ответственность?

[Электронный ресурс] / С.В. Туркин // Корпоративный менеджмент. - Режим доступа: http://www.cfin.ru/

3. Дикань, В.Л. Етичні основи бізнесу [Текст]: підручник / В.Л. Дикань, В.В. Компанієць, О.М. Полякова. Харків: УкрДАЗТ, 2012. - 316 с.

4. Дикань, В.Л. Стратегічне управління [Текст]: навч. посіб./ В.Л. Дикань, В.О. Зубенко, О.В. Маковоз, I.В. Токмакова, О.В. Шраменко - К.: «Центр учбової літератури», 2013. - 272 с.

5. Марков А.В. Альтруисты и паразиты / А.В. Марков // Наука в фокусе. 
- М.: Вокруг света, 2012. - №3. - С. 21-26.

6. Панченко, С.В. Підприємництво

[Текст]: підручник / C.В. Панченко, В.Л. Дикань, О.В. Шраменко, О.М. Полякова, Ю.М. Уткіна. - Х.: УкрдУЗТ, 2016. - Ч.2. - 241 c.

7. Яневич Н.Я. Соціальні інвестиції: сутність і класифікація [Електронний ресурс] / Н.Я. Яневич // Lviv Polytechnic National University Institutional Repository. - Режим доступу: http://ena.lp.edu.ua/bitstream/ntb/11337/1/26. pdf

8. Шейман Д. Социально

ответственное инвестирование. Опыт развитых стран [Электронный ресурс] / Д. Шейман, К. Смирнова // Cloudwatcher. Лаборатория социальных инноваций.

Режим доступа: http://www.cloudwatcher.ru/userfiles/investsi te.pdf.

9. Report on Socially Responsible Investing Trends in the United States. 2017 [Электронный ресурс] // The Forum for Sustainable and Responsible Investments. Режим доступу: http://www.ussif.org/files/Publications/10_Tr ends_Exec_Summary.pdf

DOI $10.18664 / 338.47: 338.45 . v \%$ vi\%i.146085

УДК [330.34.014.1.+314.028]:504.05

\title{
КОНЦЕПЦИЯ УСТОЙЧИВОГО РАЗВИТИЯ: ЭКОЛОГИЧЕСКИЙ И НРАВСТВЕННЫЙ ИМПЕРАТИВЫ
}

\author{
Фролов А.И., к.э.н., доцент, \\ Каменева Н.Н., к.э.н., доцент, \\ Косич М.В., к.э.н., доцент (УкрГУЖТ)
}

\begin{abstract}
В статье, на основании рассмотренных качественных кризисных изменений в экосистеме планеты Земля аргументируется необходимость перехода к устойчивому развитию как новому пути цивилизационного развития, основанного на радикальном изменении ценностей и целей современного общества. Авторами теоретически обосновано, что устойчивое развитие - это путь развития человеческой циивилизации, в основе которого заложено следование общечеловеческим иенностям, позволяющее сохранять развитие системы «природа-общество-человек» в целом. Обосновывается положение о том, что в целом переход от природы к нравственности является, $c$ одной стороны, определяющим условием самосохранения человека путем сохранения среды жизни, с другой стороны, основным законом развития человеческого общества.

Ключевые слова: система «природа - общество-человек», биосфера, антропоцентризм, экология, нравственность, культура, общечеловеческие ценности, концепция устойчивого развития, экоцентризм, экологический императив, нравственный императив.
\end{abstract}

